\title{
A lucidez tardia: a poesia de Paulo Henriques Britto
}

\section{Arlenice Almeida da Silva}

Resumo: $\mathrm{O}$ artigo examina a obra poética de Paulo Henriques Britto, em particular o livro Macau, de 2003 , buscando situá-la no cenário poético contemporàneo. A partir de categorias estéticas de Adorno e do jovem Lukács, dos conceitos de moderno, ironia e autonomia da obra de arte e do diagnóstico da crise da poesia, procura-se entender como o poeta dialoga com a tradiçâo em uma forma singular que combina elementos tradicionais; como o soneto, com a informalidade coloquial. Tal diç̧ão que parte dos paradoxos da modernidade acaba tensionando a contemporaneidade ao procurar, entre outras coisas, encurtar a distància estética entre o autor e o leitor. Palavras-chave: poesia, modernidade, Adorno, Lukáes, estética.

Abstract: The article examines Paulo Henriques Britto's poetic work, particularly the book Macau (2003), in order to place it in the contemporary poetic scenario. From the aesthetic categories of Adorno and the young Lukics, the concepts of modern. irony and autonomy of the work of art and of the diagnosis of the crisis of poetry seek understand how the poet dialogues with the tradition in a particular way that combines traditional elements, as the sonnet, with colloquial informality. This diction, which departs from the paradoxes of modernity. ends in tensioning contemporary to seek, among other things, shorten the distance between the author and aesthetic of the reader. Keywords: poetry; modernity, Adorno, Lukä́cs, aesthetics. 
Não, essa voz não é tua.

Você não tem voz própria, tal como

não é dela a luz da lua, no céu,

esse quarto minguante incompetente que mal

e porcamente alumia, essa tosca

arandela de santo em quarto de bordel,

coberta de cocô de mosca...

Não abre a boca, não estufa

o peito, não. Nada que você diga

é teu. Nada é você. Você não é. Puf!

Assim termina o último dos "Dez sonetoides mancos", de Paulo Henriques Britto, nos quais o poeta compartilha com o leitor, mais uma vez, a desilusão com o verso. Com uma entonação enérgica, num ritmo marcado por repetições de negações enfáticas - "não", "nada" -, em uma estrutura convencional, a do soneto, mas submetida a transformações - dois tercetos, seguidos de dois dísticos e numa solução de contenção que resulta, por essa razão, em dez versos "mancos" -, o poeta plasma, em imagens poéticas, conteúdos discursivos, densos e profundos. Não seria pouco o espaço, denotando um desequilíbrio originário e irreversível? Como o poeta equaciona a relação entre um máximo de sentido e um mínimo de palavras? De um lado, as rimas irregulares fornecem aos versos um ritmo seco e contundente. De outro, afrontando a experiência do leitor, zombando ao desmascarar as imagens banais que ainda o seduzem ("a luz da lua, no céu"), o verso agride ("esse quarto minguante incompetente que mal e porcamente alumia") e, sem justificativa plausível ao leitor, nega-lhe qualquer identidade, sustentado tão somente pelo efeito de um único referente material: "essa tosca/ arandela de santo em quarto de bordel,/ coberta de cocô de mosca.../"

Desse modo, a breve extensão, feita não de economia e síntese, mas de amputação, resulta, evidentemente, no desequilíbrio manco. Tal falta, contudo, não é falha, $\mathrm{e}$ sim o elemento formal que exacerba o movimento demolidor repetido nos outros nove sonetoides, em que o poeta insiste no mesmo processo de desencantamento.

1 BRITTO, Paulo Henriques. Macau. São Paulo: Companhia das Letras, 2003, p. 66. 
A ambiguidade instaura-se, de pronto, na primeira estrofe do sonetoide I, pois no exato instante em que o leitor carente provavelmente começa a fraquejar e identificar-se com a fala do poeta - "melhor seria simplesmente ser, sem preocupar-se/ em ser original" - ${ }^{2}$ e, sentindo-se acolhido, em uma pátria qualquer, timidamente pensa concordar e percorrer o mesmo caminho, é arrancado de seu sono poético pelo verso: "naturalmente sei que isto é banal". Esse procedimento culmina no quinto sonetoide com a já manjada e desavergonhada apropriação do mote baudelairiano da modernidade: "E assim tornamo-nos, senão irmãos, leitor hipócrita,/ ao menos cúmplices, você e eu". Tal recurso assinala que leitor e autor, devidamente identificados pela e na linguagem, sabem desde o início em que terreno estão pisando: "Sim, você é um/ dos nossos. Pode entrar. A gente não morde".

Nada aqui aponta para o novo, nem para o novíssimo: o poeta não engana, exibe suas heranças e filiações, diz qual é o jogo, convida-nos a participar dele ressaltando, contudo, de antemão, que não há vencedores, só perdedores. Desde Liturgia da matéria (1982), Mínima lírica (1989) e Trovar claro (1997), Paulo Henriques Britto constrói um projeto consistente que procura dar forma a uma lírica que não seja mera expressão do eu, "dessa coisa falsa que se disfarça, fingindo se expressar", ${ }^{4}$ mas linguagem de atrito com um mundo que se apresenta como corpóreo e material. Para engendrar uma forma a partir da matéria, o poeta, em sua trajetória, apropria-se, muita vez, da forma canônica do soneto, traduzindo-a em variantes, como "sonetilho", "sonetoide" ou "soneteto", que, por terem sido intencionalmente maculadas, adquirem formas mancas, trágicas, sentimentais ou grotescas.

É possível apontar na fatura de Paulo Henriques Britto dois procedimentos, em aparência antagônicos, mas convergentes, em particular nos seus "Sonetoides mancos", aqui enfatizados: de um lado, a progressão do soneto é colapsada por interrupções e involuções, que implicam a adoção de desenvolvimento irregular e, consequentemente, a ausência de coesão interna. De outro, o poeta explora o efeito do contraste: no geral, os dois primeiros tercetos introduzem reflexões teóricas e interrogações em tom sério, de apelo filosófico - na verdade, enunciados filosóficos ligeiros, digeríveis e simplórios que convidam o leitor à comunhão e à intimidade: "Também não me encontrei"; "Nada não leva a nada"; "será que é não querer o que se deseja?”; “Também já estive aí, no não lugar onde você se encontra” - contudo,

\footnotetext{
2 Idem, p. 57.

3 Ibidem.

4 BRITTO, Paulo Henriques. Um pouco de Strauss. Trovar claro. São Paulo: Companhia das Letras, 2006, p. 85.
}

178. SILVA, Arlenice Almeida da. A lucidez tardia: a poesia de Paulo Henriques Britto 
o tom sério repentinamente é abandonado por um tom menor, sarcástico, às vezes nos versos finais do soneto, às vezes ainda no primeiro terceto inicial. Rebaixamento que surge ora de um brusco deslocamento, gerando um efeito inesperado: "Não. Só a geladeira tendo um chilique" ou "coberta de cocô de mosca"; ora de uma oscilação na própria linguagem, por meio de termos retirados do uso coloquial e que encenam uma aparência de intimidade: "Ué? Já vai?"; "Bem que eu falei"; "Vai pra cama"; "Que ninguém nos ouça";"puf"; "Epa" etc.

Assim, o soneto se desvia necessariamente do seu formato tradicional, isto é, de uma estrutura que começa com uma questão, progride nela, encaminhando-se para o remate, o "fecho de ouro", no qual uma solução seria encontrada: um encantamento que confirmasse a unidade plena e perfeita da obra. Mas o desvio é só parcial, pois em Britto o soneto, a despeito de manco, não fracassa; ao contrário, os contrastes e arremates desembocam em soluções que, inesperadamente, apontam para uma coesão que, no degringolar do soneto, dá uma razão de ser a todas as suas partes.

A rigor, e como o próprio título já enuncia, aqui predomina uma chave irônica, desmistificadora, certamente filiada à tradição moderna, em especial à do satanismo baudelairiano. Reencontramos na poesia ainda "moderna" de Paulo Henriques Britto a ousada relação entre lirismo e ironia, que permitiu aos modernos radicalizarem a chave romântica. Contudo, no movimento interno de desrealização da forma soneto, que introduz irregularidade e dissonância, dotando a forma fixa de prosaísmo, o recurso irônico nas mãos do poeta aparece como negação determinada, que pede no mínimo um comentário. Há uma lucidez impudente em seus versos, uma nítida clareza de que se trata de arrombar uma porta já escancarada. Os dez sonetos são mancos não porque coxos e assimétricos, nem apenas porque anacrônicos e passadistas, ou porque repisam a vanidade dos sonhos e a quimera dos gestos, e, consequentemente da linguagem que pretende ainda anunciá-los, mas por insistirem mais uma vez no recurso cínico, em uma interpolação ao leitor já conhecida, e, mesmo assim, reiterada: "Naturalmente, sei que isto é banal [...] e a consciência disso, então... Etcétera e tal"; "Você já viu esse filme"; "Se tudo correr bem, também a tua derrota/ vai ser de bom tamanho. Pode contar comigo"; "Bem que eu falei"; "Epa. Resposta dada. Ué? Já vai?"; "Pronto. O momento já passou./ Levanta da cadeira. Vai pra cama"; "Puf"

O que pode significar para a lírica contemporânea tal recorrência? A reprodução de um modelo bem-sucedido? Até que ponto a lírica de Paulo Henriques Britto, ao retomar a tradição da modernidade, pelo viés da ironia, exemplifica as indagações poéticas contemporâneas? Em que termos podemos pensar sua historicidade? Sua 
poesia não cai na armadilha salvadora do "múltiplo", nem no mote do deciframento, no qual ambos, leitor e poeta, em comunhão, compartilhariam de um enigma que, em cascata, sempre apontaria para uma "multiplicidade de significações". Então, que efeito o poema espera arrancar do leitor?

Ao responder em tom de advertência: "não, essa voz não é tua", a lírica dirige-se diretamente a um suposto leitor-autor, buscando desarmá-lo de pronto; esse leitor exemplar que, no afã de intimidade e comunhão, busca fazer do poema sua própria voz; um leitor que se crê "sensível", pois está a ler e a fazer poemas, procurando intencionalmente forjar encantamento a partir de uma sensibilidade que se crê preservada e intacta; uma lírica que continua zombando do leitor que quer ser consolado e que acredita na poesia como uma via de acesso a seu "mais íntimo eu". Os sonetoides e sonetetos, sejam "mancos", "trágicos" ou "grotescos", de Paulo Henriques Britto, devem mais uma vez rir deste leitor que é romântico, mas, sobretudo, que acredita ainda poder preservar uma interioridade incólume diante de um exterior alienado. Seguramente, nestes versos a defesa de uma interioridade autônoma, afetiva e digna é colocada sob suspeita:

Nada de mergulhos. É na superfície

que o real, minúsculo plâncton, se trai.

Sentidos, sentimentos e outros moluscos

não passam pela finíssima peneira

do funcional. E o sofrimento, ai,

esse nefando pinguim de louça

sobre o que deveria ser, na quiti-

nete do eu, uma austera geladeira...

Que ninguém nos ouça: guarda esse escafandro, meu

filho. Só o raso é cool. A dor é kitsch. ${ }^{5}$

5 Idem, p. 62 
Reencontramos aqui o mesmo movimento. A oposição séria e elevada entre profundidade e superfície que abre o vi sonetoide deságua no desfecho dialético zombeteiro de quem conhece como as hierarquias dispõem os afetos, os valores e as coisas: a dor insincera e fingida oscila entre o cool e o kitsch, par de termos oriundo do cenário cultural; "juízos estéticos" subjetivos, desinteressados, inúteis, mas determinados pelas vicissitudes das tensões sociais e pelas demandas externas. Se para Theodor Adorno, na "Palestra sobre lírica e sociedade", era o sofrimento do poeta o elemento objetivo que lhe permitia, no limite, reagir por meio da linguagem diante da sociedade coisificada, aqui a crítica é da mesma matriz, mas ainda mais profunda, pois nem o sofrimento é poupado, desmascarado na imagem do "pinguim de louça" como ícone pop: produto, bem cultural, na sociedade funcional, na qual não há espaço existencial para sentimentos pretensamente autênticos. Se o real apenas "se trai", é porque não há tampouco algum campo epistemológico transcendental ou comunicativo propenso à produção de sentido: "não há nada aqui que se explique", ninguém te implorando a presença, nenhuma mensagem imprescindível: "eu não disse? Não tinha ninguém/ batendo à tua porta a essa hora/ da noite, como era de se esperar." 6

De modo que, se estamos novamente diante da crise do verso, é para reformular os impasses da crise do sentido, no contemporâneo. Augusto Massi, na apresentação de Trovar claro, de 1997, encontra a fórmula certeira ao nomear Paulo Henriques Britto um racionalista em desassossego. "O poeta busca ideias de ordem diante do desconcerto do mundo, mas impregnado por certa subjetividade franqueia a experiência intelectual aos movimentos da intimidade. $\mathrm{O}$ racionalista em desassossego quer enterrar os seus defuntos mais familiares e desmascarar o impostor no espelho da identidade"?

Do ponto de vista quantitativo e panorâmico, isto é, do mecanismo institucional e midiático, estamos diante do fenômeno do contemporâneo: para o bem ou para o mal, Paulo Henriques Britto participa da recente efervescência da poesia, com os índices de produção que assinalam números otimistas; escrevem-se e publicam-se cada dia mais versos. A poesia tradicional em livro e a divulgada em blogs e sites têm crescido significativamente no Brasil. Um encorajamento, aliás, que não atinge apenas o fazer versos, pois o crescimento se vê em outras formas de arte. Ela está

6 Idem, p. 64.

7 MASSI, Augusto. Apresentação. In: Trovar claro. São Paulo: Companhia das Letras, 2006. 
presente em toda parte: quase tudo é artístico, nessa sociedade cultural contemporânea. Museus, exposições, publicações, feiras de arte são referências que apresentam ao público uma variedade de linguagens e produtos, sem deixarem de instruí-lo de que tais atividades artísticas são uma porta de entrada para uma mais eficaz integração na sociedade. Um cultural movido por uma potência de assimilação que incorpora tudo passivamente, ignorando as hierarquias e as diferenças estéticas.

Do ponto de vista da pesquisa formal, contudo, Paulo Henriques Britto é herdeiro assumido da tradição moderna e de seu problema central: a crise da poesia. De modo que duas temporalidades convivem em seus versos. De um lado, o moderno e a sua crise se apresentam na redução da linguagem poética a seus elementos essenciais não discursivos; quando a poesia se torna experimentação e poeticidade, nos termos hoje clássicos de Jakobson: "a palavra é experimentada como palavra e não como simples substituto do objeto nomeado, nem como explosão de emoção". De outro, a linguagem que dissolve o real, abrindo-se criticamente para o experimental, amplia cada vez mais a distância e o estranhamento em relação ao tempo. Não é por outra razão que periodicamente ressurge a exigência da integração da poesia ao ciclo tecnológico e científico da cultura contemporânea, ou seja, volta o tema do desajuste e a denúncia de que a poesia está atrasada em relação ao tempo e à margem dos meios vigentes de comunicação.

Diante deste impasse, definidor do cenário poético brasileiro contemporâneo, duas tendências conflitam, na avaliação de Alfredo Bosi, sem apresentar resultados satisfatórios: de um lado, predominam reproduções de modelos literários, "o acervo fastidioso de neomaneirismos pós-modernos" (pastiches à Oswald de Andrade, à Fernando Pessoa, à João Cabral de Melo Neto). De outro, dominam tentativas de ajustamento ao tempo, com uma produção nomeada de "cultura-para-massas computadorizada", pois "a comunicação estimulada e acelerada de modo vertiginoso permite um descarte selvagem da tradição culta, favorecendo performances compulsivas no nível do puerilismo e do brutalismo". Daí seu nostálgico diagnóstico: “é cada vez mais árdua e rara a expressão lírica pura, forte, resistente". 9

Para escapar dos limites e armadilhas destas tendências, Paulo Henriques Britto enfrenta o problema do moderno na lírica contemporânea, buscando soluções que contemplem os dois polos do impasse poético. Pois, de um lado, ainda reverbera, entre nós, o tema da autonomia da arte e a avaliação do crítico e poeta Mário Faustino, para quem a crise é positiva porque os poetas "têm o destino da poesia em suas

8 JAKOBSON, Roman. Qu'est-ce que la poésie? Huit questions de poétique. Paris: Éditions du Seuil, 1977, p. 46 9 BOSI, Alfredo. Poesia e historicidade. O ser e o tempo da poesia. São Paulo: Companhia das Letras, 200o, p. 16-17.

182. SILVA, Arlenice Almeida da. A lucidez tardia: a poesia de Paulo Henriques Britto 
mãos". ${ }^{10}$ Bem como, de outro lado, a avaliação histórica de Alfredo Bosi, em 1970, em O ser e o tempo da poesia:

a partir de Leopardi, de Hölderlin, de Poe, de Baudelaire, só se tem aguçado a consciência da contradição. A poesia há muito não consegue integrar-se, feliz, nos discursos correntes da sociedade. Daí vêm as saídas difíceis: o símbolo fechado, o canto oposto da língua da tribo, antes brado ou sussurro que discurso pleno, a palavra-esgar, a autodesarticulação, o silêncio. [...] Essas formas estranhas pelas quais o poético sobrevive, em um meio hostil ou surdo, não constituem o ser da poesia, mas apenas o modo historicamente possível de existir no interior do processo capitalista. ${ }^{11}$

\section{Culminando com o diagnóstico provocador:}

A poesia vista como uma técnica autônoma da linguagem, posta à parte das outras técnicas e bastando-se a si mesma: eis uma teoria que estende à prática simbólica o princípio fundamental da divisão do trabalho e o exalta em nome da maior eficiência do produtor. ${ }^{12}$

A poesia de Paulo Henriques Britto almeja ser de "longa duração", inserindo-se, pois, nesta encruzilhada conceitual e temporal, no coração do paradoxo da lírica contemporânea - pretensão que lança um desafio ao comentador. O problema aqui circunscrito, portanto, pode ser enunciado como o da relação entre o moderno e o contemporâneo. Contudo, à crítica não cabe apenas constatar o inusitado, mas, como sugeriu Adorno, tomar o poema como um "relógio solar histórico-filosófico", percebendo o significado das badaladas. ${ }^{13}$ Evidentemente, a relação não se esgota com o argumento do inacabado, no qual a modernidade sobreviveria ainda por ser um projeto não realizado plenamente. Tampouco anuncia soluções conservadoras como um retorno nostálgico às origens, ao pré-moderno, em que a obra reencontraria, finalmente, a coesão perdida. O poeta faz versos, pois, como Schiller, considera-se filho de sua época, mas não seu discípulo ou favorito; por teimosia, porque insiste em impedir o esquecimento, diante de uma subjetividade em crise e de uma linguagem que não pode dizer o objeto da experiência. A forma nasce desse desejo, que é saber; partindo da constatação de que

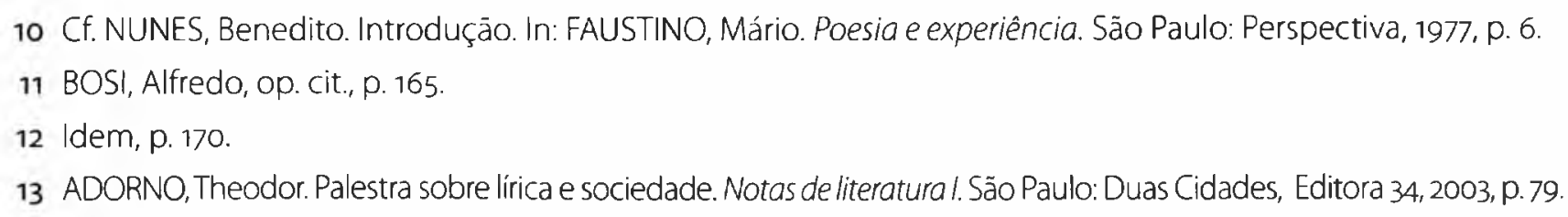


não há como voltar atrás e estabilizar o referente, dispondo-o de tal forma que apareça nele um sentido reconhecível e estável.

A propósito da correspondência entre os poetas Stefan George e Hofmannsthal, Adorno, em 1940, situou de forma complexa o caráter precário da lírica que se apresenta como herança do moderno. Se o poeta do moderno deu as costas a qualquer influência hegeliana - "o espírito que se expõe de modo espiritual por meio da representação", nos termos de Hegel - seus herdeiros devem lidar com o vazio deixado pela explosão de todas as formas categoriais que eram capazes de fixar o sujeito e o objeto. Ou seja, na medida em que tudo se torna dizível, a crise da lírica aponta para outro esvaziamento, que é o do sentido; e para o momento de ruptura, de cisão: "a linguagem não mais permite dizer o que foi o objeto de experiência. Ou ela é a linguagem reificada e banal das mercadorias, que de antemão falsifica o pensamento; ou ela se autoinstitui, cerimoniosa mas sem cerimônia, poderosa mas sem poder, apoiando-se no próprio punho."14 Um vazio que não é apenas ausência de um conteúdo determinado e, portanto, abertura ao indeterminado, mas signo de um "desmoronamento" que, negativamente, pode apontar para "aquilo que a linguagem não conseguiu dissolver" e que só pode ser percebido pela reflexão teórica imanente, colocada em jogo pela e na poesia.

O princípio da arte moderna para Adorno é a negação das pretensões de uma unidade e plenitude de sentido na obra, mas, trata-se de uma recusa histórica: a negação do sentido herdado, da forma tradicional do sistema de sentido. ${ }^{15}$ É claro que, em Adorno, na operação poética trata-se primordialmente de nomear o incomensurável, na medida em que, à poesia como presença de algo não pensável, abre-se um campo de experimentação. Contudo, ao comentar a poesia de Hofmannsthal, diz Adorno que se o "poeta do moderno deixa-se submeter pelo poder das coisas como o outsider":16

[...] e se esforça febrilmente em instaurar a própria coisa [...]. O que se deseja é fazer explodir, com o material desprovido de intenção, a realidade petrificada pelos significados tradicionais: refugiar-se em conteúdos inéditos, para que estes não sejam absorvidos por nenhuma comunicação costumeira no âmbito do existente. ${ }^{17}$

\footnotetext{
14 Idem. George e Hofmannsthal - correspondência: 1891-1906. In: Prismas. São Paulo: Ática, 1998, p. 200.

15 Cf. WELLMER, Albrecht. Sobre la dialéctica de modernidad y postmodernidad. Madri: A. Machado Libros S. A., 2004, P. 60.

16 ADORNO, Theodor, op. cit., p. 219.

17 Idem, ibidem, p. 216
}

184 - SILVA, Arlenice Almeida da. A lucidez tardia: a poesia de Paulo Henriques Britto 
O procedimento é negativo: roubar-lhes a linguagem, negar-lhes a comunicação, eis a tarefa do poeta herdeiro do moderno.

A poesia de Paulo Henriques Britto não abre mão de pensar a existência sem pudor, como base material ou ossatura do mundo; a relação entre interior e exterior, tensa, assimétrica, assinala a precariedade do primeiro termo e a hostilidade das coisas. Macau, título do seu livro de poemas de 2003, não é a terra desconhecida, da aventura e da abertura de um campo infinito de possibilidades, mas, sim, em uma inversão perversa, o "eu", esse "minúsculo império sem território" que não pode sair de dentro de si, de suas bordas, que "jamais se desprendeu / do cais úmido e ínfimo do eu". ${ }^{18} \mathrm{Na}$ II das "Epifanias triviais", o poeta confirma o beco sem saída de uma individualidade atritada com o mundo das coisas:

As coisas que te cercam, até onde

alcança a tua vista, tão passivas

em sua opacidade, que te impedem

de enxergar o (inexistente) horizonte,

que justamente por não serem vivas

se prestam para tudo, e nunca pedem

nem mesmo uma migalha de atenção,

essas coisas que você usa e esquece

assim que larga na primeira mesa -

pois bem: elas vão ficar. Você, não.

Tudo o que pensa passa. Permanece

A alvenaria do mundo, o que pesa.

O mais é enchimento, e se consome.

As tais Formas eternas, as Ideias,

e a mente que as inventa, acabam em pó,

e delas ficam, quando muito, os nomes.

18 BRITTO, Paulo Henriques. Macau, op. cit., p. 42. Pode-se perceber também na prosa personalíssima de Paulo Henriques Britto a força e a hostilidade dos objetos pressionando e definindo os limites da interioridade. Por exemplo, no conto "Um criminoso", a trama resulta da descrição dos objetos que vêm à tona diante do olhar do narrador, configurando e determinando sua percepção do mundo. Cf. Paraísos artificiais. São Paulo: Companhia das Letras, 2004. 
Muita louça ainda resta em Pompeia,

Mas lábios que a tocaram, nem um só.

As testemunhas cegas da existência,

Sempre a te olhar sem que você se importe,

vão assistir sem compaixão nem ânsia,

com a mais absoluta indiferença,

quando chegar a hora, a tua morte.

(Não que isso tenha a mínima importância.) ${ }^{19}$

As quatro sextilhas do poema acima exibem uma cadência arrastada, a despeito das rimas alternadas e simétricas, gerando um efeito de peso. Seu caráter descritivo, lamentoso, impede a irrupção intuitiva de uma verdade, em formato de celebração, daí resultarem em epifanias triviais e não gloriosas. Trata-se da experiência do olhar, entendida aqui como aquilo que resulta da "atenção", isto é, da atividade da observação e do reconhecimento operados pelo pensamento, confrontada com a indiferença daquilo que é funcional e cego, que apenas pesa e permanece, que apenas se "usa e esquece", isto é, a "alvenaria do mundo". Se é verdade que o poeta eterniza nestes versos a falência do sujeito, naturalizando-a, atinge, ao mesmo tempo, o significado mais profundo da crise contemporânea, ao vê-la por meio da contraposição entre aquilo que pensa e morre e aquilo que pesa e permanece. As primeiras estrofes confirmam a trivialidade das falências do sentido e da representação: a alvenaria pesa, pois é passiva em sua opacidade; porém permanece, pois é cega e não se consome. À medida, contudo, que as estrofes finais se desdobram, o poema ganha dramaticidade e desemboca, na última sextilha, na inesperada inversão dialética: o olhar virou alvenaria; as testemunhas da existência tornam-se cegas, passivas, indiferentes.

Neste minúsculo tratado sobre o olhar, Paulo Henriques Britto dissolve o mito do olhar ilimitado, desmistificado em olhar curto: "até onde alcança a tua vista"; um olhar guiado por "exigências cegas" que não remete, contudo, a um Tirésias contemporâneo dotado de uma clarividência enigmática, mas à mais absoluta indiferença - metástase inabordável. Ainda, se o poeta parece recair de forma idealista na terceira sextilha ao abrigo das ideias platônicas, e ao tema central do "Crátilo" - a discussão sobre o caráter convencional ou não do signo linguístico - é tão só para condenar, na sequência, a ilusão de qualquer visão filosófica, em particular, a tese segundo a qual "quem co-

19 Idem, ibidem, p. 70-71.

186 - SILVA, Arlenice Almeida da. A lucidez tardia: a poesia de Paulo Henriques Britto 
nhece o nome conhece também a coisa"; para sugerir de modo ainda mais corrosivo a nulidade de um saber poético decorrente de signos arbitrários, pois se é verdade que as "coisas se prestam para tudo", diz o poeta, "as tais Formas eternas, as Ideias,/ e a mente que as inventa, acabam em pó". Se os nomes ficam, o que importa é o que se perde, os lábios, isto é, a experiência da morte; a morte vivida como pura indiferença, como aquilo que se consome sem deixar rastros. O mesmo pode ser visto no poema intitulado "De Vulgari Eloquentia", no qual o poeta diante do difícil acesso à realidade ("coisa delicada, de se pegar com a ponta dos dedos") volta ao tema daquilo que pesa e, por segundos, finge acreditar no poder autônomo das palavras: "são as palavras que suportam o mundo,/ não os ombros", mas encerra o poema em tom irônico: "portanto, meus amigos, eu insisto: falem sem parar. Mesmo sem assunto".20

Os versos do poeta partem da crise da subjetividade, mas a ela não se acomodam. Constatar que o sujeito se constitui pela linguagem e na linguagem, ou que ele é o resultado de múltiplas práticas discursivas, descentrado, constituinte, que nunca existiu o tal sujeito coeso, centrado, autônomo, que certa filosofia insistia em propalar, não resulta em postular necessariamente uma reconciliação que se dê no múltiplo, nem na energia liberada na mobilização de diversas figuras de subjetivação. Dito de outro modo, a instabilidade e a precariedade do sujeito não são em si a "chave de ouro" da poesia de Britto. A ironia do poeta não é amena, seus versos ferem, pois ainda visam a arrancar o leitor da sua passividade: "Porém há quem se preste a esse papel esdrúxulo,/ como há quem não se vexe de ler e decifrar/ essas palavras bestas estrebuchando inúteis, / cágados com as quatro patas viradas pro ar" Ao expor o modus operandi do autor-leitor, os versos não estão apenas mais uma vez repensando o fazer poético, a insuficiência da linguagem, ou o limite da representação, mas considerando o efeito, esperando por uma voz "do outro lado da linha formigando de estática,/ dizendo algo mais que testando, testando, um dois três,/ câmbio?"” ${ }^{21} \mathrm{O}$ algo a mais não permite dizer o que foi o objeto da experiência, irremediavelmente perdida no esquecimento, mas, como dizia Valéry: o poema não é apenas linguagem dentro da linguagem, mas linguagem que internamente produz "efetivas e eficazes variações da língua, ou seja, quer viver ainda em uma vida totalmente diferente. Ela adquiriu valor; e adquiriu-o em detrimento de seu significado finito, criou a necessidade de ser ouvida ainda". ${ }^{22}$

\footnotetext{
20 Idem, ibidem, p. 18.

21 Idem, ibidem, p. 19.

22 VALÉRY, Paul. Poesia e pensamento abstrato. Variedades. São Paulo: Iluminuras, 1991, p. 208.
} 
A alternância entre o estilo elevado e o rebaixado, a utilização de formas e métricas tradicionais combinadas com a informalidade coloquial, resulta não só de uma "estreita relação com a língua inglesa e do corpo a corpo com poetas da sua eleição como Wallace Stevens, Eizabeth Bishop e James Merril", como defende Augusto Massi, ${ }^{23}$ mas também da necessidade que sente o poeta na contemporaneidade de encurtar a distância estética entre autor e leitor com as armas da tradição moderna, isto é, com os meios lógicos de uma ínfima conexão temporal. Para não cair na banalidade do nada, e rascunhar os limites da experiência, o poeta procura não fazer tabula rasa do passado.

No poema de abertura do livro Tarde, de 2007, intitulado “OP. CIT., PP. 164-65", ao zombar da impostura e inutilidade da teoria diante do poder dos versos, o poeta exibe uma clareza surpreendente sobre sua própria poesia. À lírica contemporânea resta pôr-se a caminho, a partir do paradoxo da modernidade - que já estava presente em Fernando Pessoa -. ou seja, da tensão entre a "necessidade de exprimir-se uma subjetividade numa personalíssima voz lírica" e a "consciência crítica" de um sujeito que sabe ser tal tarefa impossível, e que assim, lúcido, "se inventa e evade", "desconstrói seu artifício", expondo o que em si é falso ou puro fingimento. O moderno perpetua-se no contemporâneo por meio do mal-estar provocado pela inevitabilidade de uma "postura cínica". ${ }^{24} \mathrm{O}$ cínico aqui, contudo, não é descaso, mas ironia no sentido poético moderno: pressentimento de sentido recolhido num instante como "vertiginosa lucidez". ${ }^{25}$

A herança do moderno à qual o poeta ainda se agarra é a da lucidez irônica: o moderno pensado como vertigem da razão, como turbilhão, voracidade e ambiguidade: tudo é possível, mas nada é certo, tudo se confunde; a forma moderna que não é só a busca pelo novo, mas seu corolário, o reconhecimento da lucidez possível vislumbrada no instante de concentração e irrupção de um resíduo de verdade, por uma subjetividade que foi aos seus limites; a vertigem que, diante da "violência dos fatos" e do terror do mundo moderno, reage configurando uma palavra-murmúrio, um balbucio que interrompe o silêncio provocado pelo excesso de transformações. A referência explícita a este conceito de moderno encontra-se, curiosamente, no jovem Lukács, no ensaio intitulado "O instante e as formas", parte da coletânea $A$ alma e as formas (1910) - texto seminal sobre a modernidade,

23 MASSI, Augusto, op. cit.

24 BRITTO, Paulo Henriques. Tarde. São Paulo: Companhia das Letras, 2007, p. 9.

25 Idem, ibidem, p. 87.

188 - SILVA, Arlenice Almeida da. A lucidez tardia: a poesia de Paulo Henriques Britto 
matriz do pensamento adorniano. ${ }^{26}$ Nesse artigo, de 1908, Lukács introduz o conceito de vertigem para pensar a relação problemática entre as formas poéticas e a modernidade: "Toda obra literária conduz aos grandes instantes, nos quais perspectivas são vislumbradas diante das profundas sombras de um abismo, ao qual devemos descer lentamente. E o desejo de ser precipitado é o conteúdo escondido de nossa vida; nossa consciência procura evitá-lo o maior tempo possível, mas ele está continuamente aos nossos pés, sob a forma de vertigens vivenciadas no topo de uma montanha, pelo fato de que perspectivas foram abertas ao acaso, de modo inesperado" ${ }^{27}$ Para o jovem Lukács, a metáfora da atração pelo abismo (Abgrund) ${ }^{28}$ alude à percepção do moderno como turbilhão: toda forma busca salvar o eu do entorpecimento diante do dilema, colocado pelo tempo, entre arrebatamento ou resignação, retardando, assim, o movimento da queda diante do precipício. De um lado, as formas resistem ao emudecimento ao figurar o instante em que a vida em sua multiplicidade se precipita no nada e no vazio; de outro, elas enfrentam a renúncia, superando a carência de linguagem frente à própria experiência e à realidade, com uma outra linguagem na qual o inefável se torna dizível e aquilo que estava encerrado na experiência individual, acessível e transmissível. Se não é mais possível a constituição de uma unidade significativa entre alma e natureza, simbólica e substancial, resta o discernimento de que a lírica não é neutra nem pode mais ignorar o mundo opaco e alheio ao sentido, inapreensível e impenetrável.

A retomada da reflexão sobre os gêneros, e nesse artigo em particular sobre o lírico, ensejou a via para o jovem Lukács enunciar o "problema espiritual (seelisch) do homem moderno". Os sinais dos novos tempos, contudo, não são encontrados em formas nomeadas "intelectualmente modernas", mas em outra forma, paralela, duplamente experimental e clássica, designada "a nova poesia da palavra" (Wortdichtung) ou "lirismo das relações humanas". Este novo lirismo apontava para o contexto do

26 A formação filosófica de Adorno foi fortemente marcada pelo pensamento do jovem Lukács, especialmente por obras como A alma e as formas e Teoria do romance. Com as obras da maturidade, deu-se o oposto: uma oposição veemente de Adorno contra o filósofo húngaro que havia, nos seus termos, forjado uma "reconciliação extorquida". Cf. TERTULIAN, Nicolas. Adorno-Lukács: polêmicas e mal-entendidos. In: Margem Esquerda, São Paulo: Boitempo, n. 9, p. 61-81, junho de 2007.

27 LUKÁCS, Georg. L'instant et les formes. L'ame et les formes. Paris: Gallimard, 1974, p. 187.

28 O tema do Abismo ressurgirá a partir dos anos 1930 em um novo contexto, na estética agora claramente marxista de Lukács. Ele aparece de forma crítica como ein Grand Hotel Abgrund, isto é, como denúncia da irrelevância e impotência da percepção do filósofo, confortavelmente instalado em um "Grande Hotel Abismo", do mundo contemporâneo como pura negatividade.

Teresa revista de Literatura Brasileira [10|11]; São Paulo, p. 174-191, 2010. - 189 
declínio da tradição do canto popular e o da ascensão do lirismo musical de formato inglês, quadro o qual, de certa forma, o maduro Goethe já antecipara e de que Stefan George, o discípulo alemão de Mallarmé, seria o principal nome, além de Hofmannsthal e Beer-Hofmann.

Para Lukács, em George a "técnica dos grandes instantes" é o que possibilita ao poeta "olhar a vida nos olhos", apenas para constatar que os "homens estão sós na natureza, em uma solidão mortal e sem remédio" ${ }^{29}$ Hofmannsthal simplifica suas figuras, reduzindo suas qualidades ao estritamente necessário. Em Beer-Hofmann, a concentração é o que permite um "face a face trágico" que abre um acesso ao instante como potência soberana e simbólica. O primado do instante não significa que a consciência libertada do peso do tempo e da presença dos acontecimentos externos pode agora se movimentar livremente em direção ao passado ou ao futuro, mas que, tragicamente, restou ao sujeito moderno apenas o instante como o momento de lucidez máxima no qual ele confronta sua impotência diante do mundo reificado. O instante é concentração só ao preço de um esvaziamento do seu conteúdo externo: "lampejos repentinos de sentido". ${ }^{\circ}$

O conceito de autonomia da obra de arte ganha, assim, nos ensaios de A alma e as formas uma tradução desencantada. O que significa que o jovem Lukács, fortemente hegeliano, leva realmente a sério a ideia de que uma subjetividade não pode saltar, por seus próprios meios, por cima de seu tempo. E o tempo é o da dissonância, da nostalgia, da impossibilidade da essência, enfim, da busca infeliz e irônica, ou seja, de uma "época não artística". Se, em Hegel, Schiller marcava o momento mais "agudo" da lírica, pois "ele não canta silenciosamente em si mesmo", o jovem Lukács, a solidão de Stefan George resulta de um quadro de abandono e

29 LUKÁCS, Georg. La nouvelle solitude et son lyrisme. L'ame et les formes, op. cit., p. 145

30 Apesar de não se referir às obras de Lukács, Erich Auerbach em vários momentos se aproxima da reflexão do filósofo húngaro. O conceito de "moderno" apreendido nos romances de Virginia Woolf e de Marcel Proust assinala igualmente uma nova concepção do tempo. O escritor moderno abandonou-se ao acaso e às contingências, não buscando mais compor e ordenar o tempo plenamente; ao contrário, faz do instante, de um fragmento escolhido ao acaso, o elemento que libera e desencadeia "processos da consciência", realidades mais profundas; camadas de consciência que remetem a um tempo multifacetado. Mas, diferentemente de Lukács, o moderno para Auerbach não tem uma dimensão trágica, pois resulta da "confiança de que em qualquer fragmento escoIhido ao acaso, em qualquer instante, no curso de uma vida, está contida e pode ser representada a substância toda do destino." Cf. AUERBACH, Erich. Mimese. São Paulo: Perspectiva, 1974, p. 480-498.

31 HEGEL, G. W. F. Cursos de Estética. São Paulo: Edusp, 2004, p. 189, v. IV.

190 - SILVA, Arlenice Almeida da. A lucidez tardia: a poesia de Paulo Henriques Britto 
declínio - "ninguém tem necessidade de lieds" ${ }^{32}$ Se não é o fim da poesia, como queria Hegel, é sinal, sim, de uma "mutação na arte", nos termos de Gérard Lebrun $^{33}$, que lhe franqueia um mergulho na interioridade sem precedentes, um devotamento a seus "cursos interiores", àquilo que na sua experiência é o mais pessoal. Mas, negativamente, tal mergulho "não anuncia nada de verdadeiramente decisivo sobre seu verdadeiro ser", diz Lukács. Em George, tal lirismo que se atém ao que é mais pessoal adota um tom de despistamento de forte inspiração em Mallarmé, como se procurasse dissimular os elementos confessionais, evitando, assim, qualquer identificação e reconhecimento por parte do leitor. Lukács demonstra que o procedimento, se não resulta, como em Mallarmé, no aniquilamento da realidade, decorre de um afastamento de toda a realidade empírica, portanto, de um lirismo que negativamente e intencionalmente se afasta de qualquer comunhão com o leitor. Lirismo "simbólico" "universal", mas, principalmente, "pudico" e "enigmático". Procedimento que coloca o poeta cada vez mais solitário e afastado da vida.

Os versos pudicos e radicais de Paulo Henriques Britto e sua propensão, ao mesmo tempo, histórica e universal permitem situá-los nesses impasses da lírica moderna, tal como vividos na contemporaneidade. Em Art poétique, por exemplo, o poeta encara sua arte como uma "porrada de problemas - insolúveis" Pois, mesmo sabendo de antemão que não há interlocutores e que toda comunicação está interrompida - que ela é "um escrever que é verbo intransitivo/ que se conjuga numa só pessoa", "se nem mesmo soa,/ como haveria de querer dizer/ alguma coisa que valesse o vão/ e duro esforço de fazer sentido?" -, o poeta escreve, nem que seja para confrontar os limites da máxima kantiana da comunicabilidade universal: "Por outro lado, a coisa dá prazer./ Dá uma formidável sensação/ (mesmo que falsa) de estar sendo ouvido". ${ }^{34}$

O sentido de Tarde, título da recente obra de Paulo Henriques Britto, remete ao crepuscular: discernimento provocado pelo instante em que ao mesmo tempo as coisas ganham uma visibilidade pungente e começam a perder nitidez; mas aponta também para a sensação paradoxal de se ter chegado tarde demais: "Todas as sílabas imagináveis soaram./ Nada ficou por cantar,/ nem mesmo o não-ter-mais-o-que-cantar,/

32 LUKÁCS, Georg, op. cit., p. 136.

33 LEBRUN, Gérard. A mutação da obra de arte. A filosofia e sua história. São Paulo: Cosac Naify, 2006.

34 BRITTO, Paulo Henriques. Tarde, op. cit., p. 54. 
o não-poder-cantar, já tão cantado/ que estiolou no infinito banal/ de espelhos frente a frente a refletir-se". ${ }^{35}$ Tal sensação refere-se a uma relação com um presente inapreensível, fugidio, vivido pelo poeta como aquilo que escapa; que nunca se pode ter ou pegar. Se o passado é o que foi destruído e irremediavelmente perdido enquanto experiência, e o presente é o que foge veloz, incompreensível, como imaginar "uma forma de vida que se anuncia,/ ainda hesitante. Mas insistente/", ${ }^{66}$ senão como puro fingimento? Como evitar a constatação de que só resta "estar o tempo todo atento/ à aproximação do desastre"? E resignar-se a "nunca não ser ninguém nem nada,/ porém deixar-se estar no tempo/ como se ainda fosse água"? ${ }^{37}$

Buscando os limites da lucidez, a operação poética de Paulo Henriques Britto insiste em "perseguir o agora" designando o prazer pelo negativo, como consciência do fingimento; evitando perder-se em águas turvas, os versos aludem à lucidez máxima possível, diante da "opacidade das coisas". Movimento no qual o moderno se enrosca em formas do passado que, mutiladas, despojadas, quase nuas, ressurgem com a tarefa sempre infinita do recomeço, de fazer reviver de algum modo um sujeito da representação-no-mundo, mesmo sabendo tratar-se de um empreendimento inútil. Sua grande força é a honestidade: forjar formas imersas na vida, nas quais os abismos e fissuras do tempo são docemente incorporados ao verso. A leitura de seus versos não promete esperança, mas apenas a possibilidade do rascunho, do recomeço, de "reinventar a manhã". Eis o "ácido saber de nossos dias". A brutalidade deste saber, sem esperança alguma, sem utopia, deve causar estranhamento e incômodo, não naturalidade ou resignação.

Edgar Allan Poe, nas considerações sobre o efeito da poesia, em "Filosofia da composição", inaugurava a modernidade, em 1845, expondo seu processo produtivo, mas ainda sustentando de forma idealista a "intensa e pura elevação de alma que se experimenta em consequência da contemplação do belo". Em oposição às pretensões sérias dessa "Filosofia", Paulo Henriques Britto ironiza contrapondo, com recursos mínimos, uma "Fisiologia da composição". Da filosofia para a fisiologia, da representação para o funcionamento, da profundidade para o raso: o poeta percorre um intervalo que não é puro vazio, mas território preenchido por um principium stilisationis, forma-fragmento de experiência perdida; vestígios de uma história da subjetividade da qual o poeta tenta precariamente salvar alguns resíduos.

\footnotetext{
35 Idem, ibidem, p. 84.

36 Idem, ibidem, p. 55.

37 Idem, Macau, p. 25
}

192 - SILVA, Arlenice Almeida da. A lucidez tardia: a poesia de Paulo Henriques Britto 
Sua "fisiologia" não é pastiche ou paródia, mas fiapo de nexo histórico, vertigem de sentido, lucidez, melancolia; dialeticamente, "palavras tardias" que diante de um agora imobilizado chegam "mais tarde ainda":

\author{
A opacidade das coisas \\ e os olhos serem só dois. \\ A compulsão sem culpa \\ de dar sentido a tudo. \\ O incômodo pejo \\ de ser só desejo. \\ Por fim, $\mathbf{o}$ acaso. \\ Sem o qual, nada. ${ }^{38}$
}

Arlenice Almeida da Silva é professora de Estética na Universidade Federal de São Paulo. É autora de As Guerras da Independência (Ática, 1995).

38 Idem, p. 13. 